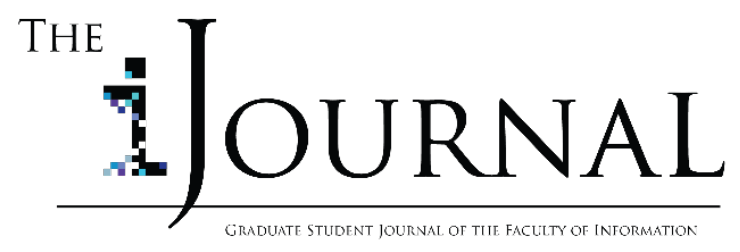

Leeves, Sarah. (2020). The iJournal Vol 5, Issue 2, DOI:

10.33137/ijournal.v5i2.34414

\title{
Exploring the Convergence of
}

\section{House Museums and \\ Community Archives}

\section{Sarah Leeves}

\section{Abstract}

Current trends in the heritage field suggest that libraries, archives, and museums may benefit from working together, sharing resources, and sharing spaces - be it on the web or physically. This paper will argue that one type of museum, the house museum, would benefit especially from converging with local community archives. Community archives provide visitors with a direct connection to their community through their specialized collections and intimate focus. Meanwhile, house museums allow for a level of immersion in the exhibit that purpose-built museums do not. Their local focus also ties them to a specific community, just as community archives are tied to their local community. Together, house museums and community archives can provide a more nuanced understanding of history to their community and improve the social standing, resources, and outreach of both institutions.

Keywords: Convergence, Archives, Museums

(C) 2020 Leeves, Sarah. This is an Open Access article distributed under CC-BY. (c) (i) 
Libraries, archives, and museums (LAMs) are all heritage institutions that provide information services to the public. While each institution approaches their task quite differently, their main purpose of serving the public remains the same. Current trends in the heritage field suggest that LAMs may benefit from working together, sharing resources, and sharing spaces, be it on the web or physically. This paper will argue that one type of museum the house museum - would especially benefit from converging with local community archives. The convergence of house museums and community archives has not been thoroughly analysed in recent convergence literature, even though the potential increase in visitors, funds, and awareness would greatly benefit both institutions. Most research in LAM convergence focuses on national institutions or digital collaboration between libraries, archives, and museums (Duff et al., 2013). House museums themselves allow for a level of immersion in the exhibit - which can be seen as an archival record itself - that purpose-built museums do not allow. Additionally, their local focus ties them to a specific community, just like community archives are tied to their local community. However, house museums are often seen as overly sanitized spaces that focus on a single social group, family, or story. The restrictive nature of museums - house museums included - would benefit from the inclusion of more archival material that displays less prominent stories. Many popular house museums across North America emphasize underrepresented populations, allowing for greater interaction and connection with the general public. The first part of this paper will establish the potential for convergence and how house museums and community archives would benefit from collaboration. Ways to de-sanitize and open house museums to more populations and interpretations will be explored in the second part of this paper, along with positive examples from North American house museums.

The convergence of libraries, archives, museums, and sometimes galleries has been a popular topic among information professionals since the early 2000s. Libraries, archives, and museums were "conceptually closer" when they were created as public institutions in the eighteenth century, all considered to be places of "cultural heritage and memory institutions" (Duff et al., 2013, p. 2). However, they have since differentiated themselves and now have unique mandates, goals, and theoretical frameworks that have altered the function of each (Duff et al., 2013, p. 2). Each institution has its own process for training professionals, and their education is often not cross-compatible (Urban, 2014, p. 597). While cross-disciplinary programs such as iSchools exist around the world, there is still a lack of communication between the three groups. Researchers call for new information professionals who can "transcend the traditional boundaries between libraries, archives, and museums," especially in the current information age (Marty, p. 624 as cited in Warren \& Matthews, 2018, p. 25). Historically, one of the main differences between LAMs was that they managed different types of materials and appealed to different populations or types of audiences (Urban, 2014, p. 597). However, since the development of digital technology, many LAMs have begun to manage the same types of information - that is, digital information.

In the digital world, the delineation between libraries, archives, and museums has grown increasingly blurry. It is especially common for government-based LAMs to share websites or 
at least interlink their web presences. For instance, Library and Archives Canada has one website for both institutions. On the other hand, convergence of the United Kingdom's LAMs was attempted in 2012 but later abandoned due to financial difficulty (Warren \& Matthews, 2018, p. 20). Australia is considered a world leader in LAM convergence, adding galleries to the mix of shared cultural heritage institutions (Warren \& Matthews, 2018, pp. 22-21).

Contemporary users, Warren and Matthews note, do not care which institution their information comes from - they just want "the stuff," preferably with online access (Warren \& Matthews, 2018, p. 40). With the increase in digital media, the differences between libraries, archives, and museums have become even less apparent, as all institutions must now manage these media. In 1998, Rayward suggested that digital media would lead to the reintegration of LAMs, at least "from the perspective of users and researchers" (as cited in Urban, 2014, p. 597). But what about their physical objects? Budget constraints and rising infrastructure costs, especially in downtown areas, may lead to the convergence of more than simply website URLs.

The convergence of already-existing libraries, archives, or museums that overlap in mandate with other similarly focused institutions is one way in which LAMs can overcome their current financial and outreach issues. House museums and community archives are one pair of similar institutions that may benefit from convergence. In museums, the public can enter an exhibit, but the exhibit does not display the full context of the displayed records. In archives, the public can handle a record and understand its full context by exploring the rest of the collection. House museums are a type of museum that allows for greater immersion within the exhibit than regular museums, existing as an institution between museums and archives. In a house museum, the public can actually enter the record. Even the term "house museum" is somewhat oxymoronic, referring to both a place that someone lives and a place "frozen in time" (Stone, 2013, p. 28). A house is where history is created, where a family grows old together as the home changes to reflect its development. Meanwhile, a museum is full of exhibits that rarely change and tend to be set in a specific time period, location, and viewpoint. A house museum is no longer lived in - it has been reset to a specific time period, but it still maintains the history of a family and their place in the world.

As oxymoronic as they are, house museums are a unique type of museum that allows for full immersion in a family's daily life. Many house museums even employ actors to pose as family members or people from the community to increase the immersive experience. The physical authenticity of a house museum makes it more similar to an archive, which attempts to preserve record authenticity via context, than a museum, which has a purpose-built context often designed to tell only one story. Although museums do not call their objects records, it could be argued that all museum objects are simply records out of context. According to the International Council of Archives, a record is any "recorded information produced or received in the initiation, conduct or completion of an institutional or individual activity and that comprises content, context and structure sufficient to provide evidence of the activity" (as cited in Ross, 2018). Thus, museum objects are a type of record that curators attempt to put back in context, though this is often an artificially constructed context. 
Since house museums only represent the items found in that house, they avoid this contextual problem entirely: objects in house museums are archival records in their true context, presented to the viewer as a type of three-dimensional, walkable, immersive archive. The building these objects are housed in, the house itself, becomes essential to the context and portrayal of the collection. As Stone writes, a house museum's "collection's most meaningful context [is] its original location" and "no parts [are] extraneous to its history and therefore its meanings" (2013, p. 30). The bond between individual records is displayed throughout the house, from the room objects are housed in, to the aesthetic placement of each item. The context is on display for the public to interpret themselves, often with little information other than what can be seen visually. This allows house museums to be completely immersive experiences while still allowing visitors to create their own path, their own story, as different objects are seen by different viewers.

Although house museums do allow for a multitude of interpretations, they can be overly restrictive, sanitized spaces with a singular viewpoint. As Stone writes, the "process of turning homes into museums often errs on the side of museum," by which she means that the homes can become overly sanitized and lifeless (2013, p. 32). Many houses have their architecture and furnishings overly preserved, erasing signs of life from the house as they erase wear and tear on the records (Stone, 2013, p. 32). Additionally, in order to reduce further damage, house museums restrict access to much of the home. Velvet ropes, Plexiglass gates, and watchful attendants prevent visitors from fully immersing themselves in the experience (Stone, 2013, pp. 32-33). For house museums to avoid over-sanitization, they must focus on telling multiple stories, embracing new points of view, and resisting the urge to "beautify" the house and its history. Archival material can help house museums find new perspectives to display while advertising the existence of another similar institution to an audience that is already interested in local history.

House museums can also fall prey to presenting a single story instead of a well-rounded view of the era and place they depict. As James P. Vaughan said in a lecture about historic houses, there are "too damn many spinning wheels and too few examples of $20^{\text {th }}$ century lifestyles" (cited in Carson, 2008, p. 13). House museums can depict "tired and antiquated" homes that are "disconnected from current issues and from their communities" (Carson, 2008, p. 13). In some house museums, finding an alternate story can prove to be difficult. Not much information may be known about the lower-class workers, such as servants or labourers. Many plantations struggle to present an equal view of slaves and slave owners, and most of the homes that have been preserved were owned by privileged, upper-class families who could afford to donate their house to a historical society or the government. Because of this, most house museums depict a lifestyle alien to the majority of visitors - there are not enough house museums that viewers can relate to (Carson, 2008, p.13).

The difference between a relatable and unrelatable house museum can be epitomized by two house museums located on Prince Edward Island, Canada. The first museum, Beaconsfield Historic House, is a large Second Empire and Italianate-influenced home designed by a prominent local architect, William Critchlow Harris, for one of Prince Edward Island's most 
successful shipbuilders, James Peake Jr (Historic Places, "Beaconsfield”). The second house museum is Green Gables, a farmhouse that was built in stages and is a style very common to PEI and other rural communities in Canada (Historic Places, "Green Gables"). While Beaconsfield displays the life of an upper-class household, Green Gables depicts a workingclass family home. Upon entering the Green Gables house, visitors with a farming background may recognize the wallpaper, furniture, and knick-knacks, which are common across farming communities in Canada. While not all visitors have a shared farming background, the house provides another means of personal connection by quoting passages from the Anne of Green Gables book series, establishing the setting as somewhere the visitor may be familiar with from the novels. Green Gables depicts a working-class home and uses the novels to situate the visitor in time and space. While Beaconsfield is beautiful and an expertly designed house museum, it lacks a personal touch, becoming over-sanitized. House museums that allow their visitors to connect with the home through a shared history increase immersion in the exhibit and allow for a greater understanding of the time period. While house museums can also be a source for new information, their ability to validate a person's own history is unique, as many heritage institutions cannot do so. Although houses seem to tell only one story, house museum curators should strive to incorporate stories from their local community (Stone, 2013, p. 31). When house museums stick to the single story of wealthy families, they forsake their special ability to connect with their visitors on a personal level.

Despite coming from different types of institutions, both house museums and community archives have the unique ability to engage their local community with a shared sense of history and purpose. Although the term "community archive" is somewhat contested, it is used to generally refer to any collecting and housing initiative that reflects the needs of a specific group (Flynn, 2011, pp. 146-147). The Community Archives and Heritage Group writes that community archives "seek to document the history of all manner of local, occupational, ethnic, faith and other diverse communities" (Flynn, 2011, p. 148). Since community archives exist in many different formats, defining a community archive is most often based on the archive's activities rather than form (Flynn, 2011, p. 147). Like house museums, community archives can display information about a specific subset of the population. Often, community archives serve underrepresented populations, legitimizing their history and having an important epistemological and ontological impact on their community (Caswell, Cifor, \& Ramirez, 2016, p. 35). The social impact of community archives can lead to feelings of inclusion and belonging to otherwise ostracized communities who have not seen their stories reflected in formal heritage institutions (Caswell et al, 2016, p. 35). Just like the Green Gables Heritage Place legitimized the experience of a late eighteenth century Canadian farmhouse and created a connection to farming communities across Canada, community archives have the power to legitimize communities, their experiences, and their history.

Queer archives, such as Toronto's Canadian Lesbian and Gay Archives (CLGA), are a perfect example of community archives' ability to legitimize a community. The CLGA was founded in 1973 and its mandate is to "acquire, preserve, organize, and provide public access to information and materials in any medium, by and about LGBTQ+ people, primarily produced 
in or concerning Canada” (CLGA, “About Us"). The CLGA provides Toronto's queer community with a sense of history, the ability to research their community's past, and an important record of their struggles to gain recognition and respect in Toronto. Like many community archives, the CLGA collects a wider variety of material than traditional archives, and these items may be copies instead of originals (Flynn, 2011, p. 147; CLGA “About Us"). Not only can community archives represent traditionally underrepresented populations, but they can challenge misrepresentations and correct absences in the public heritage sector (Flynn, 2011, p. 155). Communities represented in community archives can develop a "greater sense of self-belief and esteem" by seeing their own community represented in such a positive way (Flynn, 2011, p. 155). Sadly, community archives often struggle financially and can have difficulty with outreach, resources, and space (Zavala, 2017, p. 213). The CLGA, despite being one of the largest independent queer archives in the world, relies primarily on donations and short-term grants (CLGA, "Our Team"). Currently, the CLGA only has two full-time and three part-time employees, with over 150 volunteers contributing over 13,000 hours of additional archival work (CLGA, "Our Team"). Funding can be a major problem in the heritage sector, and community archives and house museums often receive less money because of their highly specific target audience.

Since visibility is a crucial issue for both house museums and community archives, combining forces for outreach, websites, and ad campaigns helps partners increase their fiscal power. Archives especially need to overcome access barriers, as entering an archive for the first time can be intimidating. Museums and archives can also offer different services to the user, drawing different audiences that may not be aware of the other institution's existence. A family visiting a history museum may enjoy being able to touch an archival record, while a genealogy researcher may enjoy immersing themselves in a home similar to that of those they are studying. Additionally, archives and museums offer different products: an archive is a "wholesaler" that offers pieces of information that can be used in the projects of others, while museums are "retailers" that offer direct, finished projects to users (Yakel, 2005, p. 16). Why not incorporate archival pieces in museum displays, or allow off-exhibit pieces to be listed in the archival collection? Conservation practices can also be shared, potentially saving money for both institutions. Flynn writes that "independent and community archives transcend traditional barriers between museums, libraries and archives," suggesting that community archives often act as more than simply an archive to their patrons (2011, p.147). In addition to being more than an archive, community archives could work with local house museums to further support their local patrons.

Many museums have already attempted convergence with great success. One example of the convergence of a museum, library, archive, and art gallery is the Currier Museum of Art's Zimmerman House. Although the Currier is by no means a community archive, the Zimmerman House is a house museum and the Currier holds the fonds for the Zimmerman house in their archives. The house, as well as its furniture and grounds, was designed by Frank Lloyd Wright in 1950 during his Usonian architecture phase (Currier Museum of Art). The Zimmerman archives include records of the restoration process, blueprints of the house, 
correspondence with Wright, and the personal items of the Zimmermans, including their modern art, pottery, and sculpture collection (Dickey, 2009, p. 50; Currier Museum of Art). The Zimmerman house is a museum, library, art gallery, and archive, although the archive cannot be accessed from within the Zimmerman House itself. Guests who wish to visit the Zimmerman House meet at the Currier and are bussed to the Zimmerman House, while researchers wishing to access the Zimmerman fond can request to do so at the Currier library and reading room (Dickey, 2009, p.50-51). Part of what is so fascinating about the Zimmerman House is that the records found in the archive are directly related to the house. This makes the house a more immersive experience: visitors can view the house, go back to the museum to view its floorplans or the letters written between the Zimmermans and Frank Lloyd Wright, and then take a tour of the gardens that he designed (Dickey, 2009, p. 50). The Zimmerman House Archive was inventoried at item-level and staff are now working to digitize the archive and make the collection more accessible online (Dickey, 2009, p.52). Although the Zimmerman House does not represent a specific community and cannot be considered a community archive, it does demonstrate how the convergence of libraries, archives, museums, and even art galleries is not only possible, but can be highly beneficial, especially for institutions with highly specific collections.

Community archives and house museums may already serve similar communities, especially if they are located close to each other. Two similar and closely located buildings could share space, be it an archive's reading room built on a house museum's land, or a room within the house converted into a reading room. Many community archives already make use of off-site storage; it may be possible to organize a reading room on the premises of a local, historically related house museum and a small archival holding space for requested items. For example, Beaconsfield Historic House is a beautiful, large house close to historic downtown Charlottetown. It is located very close to the Prince Edward Island archive, which is a far less inspiring building with a small, crowded reading room. Although PEI's archive is a government archive, its small size makes it similar to community archives. If one or two of the many rooms at Beaconsfield were transformed into a reading room, Beaconsfield would be a busier, livelier place and could potentially see an increase in visitors. Additionally, researchers would be physically located within a record itself, potentially from the time frame they are interested in, which would add to the experience of researching at an archive. Their websites could also be interlinked, showcasing collections that the two places have in common and how PEI's archive can be used to dive deeper into the information presented at Beaconsfield.

There are many things community archives and house museums have in common, and many ways for them to work together, share resources, and support each other. House museums would benefit from convergence because community archives introduce new stories, perspectives, and people to the museum, while community archives need inspiring spaces, improved outreach, and ways to overcome barriers to access. Together, house museums and community archives that serve similar communities or areas could converge to increase access, resources, and outreach. House museums would become less sanitized and more lived in, while community archives would become more accessible. Allowing researchers to complete their 
work in a house museum offers a degree of immersion not found anywhere else in the heritage sector, although cooperating on such an immense degree of convergence may take decades of planning. For now, increasing the link between house museums and community archives is an achievable goal that would directly benefit both institutions. After all, as Yakel writes, "preserving the record, whether it is a text, a photograph, or an object, requires collaboration among cultural resource professionals, researchers, visitors, and the public" (2005, p. 16).

\section{References}

Carson, C. (2008). The End of History Museums: What's Plan B? The Public Historian, 30(4), 9-27. https://doi.org/10.1525/tph.2008.30.4.9

Caswell, M., Cifor, M., \& Ramirez, M. (2016). “To Suddenly Discover Yourself Existing”: Uncovering the Impact of Community Archives. American Archivist, 79(1). Retrieved from https://escholarship.org/uc/item/ond5gop7

CLGA. (N.D). About Us. Canadian Lesbian and Gay Archives. Retrieved from https://clga.ca/about-us/

CLGA. (N.D). "Our Team.” Canadian Lesbian and Gay Archives. Retrieved from https://clga.ca/about-us/our-team/

Currier Museum of Art. (N.D). "Zimmerman House." Currier Museum of Art. Retrieved from https://currier.org/collections/zimmerman-house/

Dickey, A. (2009). The Currier Museum of Arts Zimmerman House: A Frank Lloyd Wright Masterpiece in New England. Art Documentation: Journal of the Art Libraries Society of North America, 28(2), 47-53. https://doi.org/10.1086/adx.28.2.27949522

Duff, W., Carter, J., Cherry, J., MacNeil, H., \& Howarth, L. (2013). From coexistence to convergence: studying partnerships and collaboration among libraries, archives and museums. Information Research, 18(3).

Flynn, A. (2011). The Impact of Independent and Community Archives on Professional Archival Thinking and Practice. In J. Hill (Ed.), The Future of Archives and Recordkeeping: A Reader (pp. 145-169). London, England: Facet Publishing.

Historic Places. (N.D.) “2 Kent Street / Beaconsfield.” Historic Places, Parks Canada. Retrieved from https://www.historicplaces.ca/en/rep-reg/place-lieu.aspx?id=5116\&pid=0. 
Historic Places. (N.D.) "Green Gables House.” Historic Places, Parks Canada. Retrieved from www.historicplaces.ca/en/rep-reg/place-lieu.aspx?id=11370.

Ross, S. (25 Sept 2019). "Class 3, Records: What are they and the concepts.” University of Toronto.

Stone, L. (2015). Playing House/Museum. The Public Historian, 37(2), 27-41. https://doi.org/10.1525/tph.2015.37.2.27

Urban, R. J. (2014). Library Influence on Museum Information Work. Library Trends, 62(3), 596-612. https://doi.org/10.1353/lib.2014.0005

Warren, E., \& Matthews, G. (2018). Public libraries, museums and physical convergence: Context, issues, opportunities: A literature review Part 2. Journal of Librarianship and Information Science, 52(1), 54-66. https://doi.org/10.1177/0961000618769721

Yakel, E. (2005). Choices and challenges. OCLC Systems \& Services: International Digital Library Perspectives, 21(1), 13-17. https://doi.org/10.1108/10650750510578091

Zavala, J., Migoni, A., Caswell, M., Geraci, N., \& Cifor, M. (2017). 'A process where we're all at the table': community archives challenging dominant modes of archival practice. Archives and Manuscripts, 45(3), 202-215. https://doi.org/10.1080/01576895.2017.1377088 